\title{
Emotional Intelligence, Organizational Commitment and Job Performance in the Private Hospital
}

\author{
Abdul Haeba Ramli*, Fairynda Novariani \\ Master of Management \\ Universitas Trisakti \\ Jakarta, Indonesia \\ *abdul.haeba@trisakti.ac.id
}

\begin{abstract}
This investigation is aimed to anatomize the effect of Emotional Intelligence and Organizational Commitment to Job performance. The investigation was carried out with a sample of 251 respondents from Private Hospital. The collected data was anatomized using structural equation modeling (SEM) with the help of Lisrel and SPSS were used to verify the hypothesis. The result was Emotional Intelligence has positive and significant towards Job performance and Organizational Commitment, then Organizational Commitment has positive effects and significant towards Job performance, and Employees' Organizational Commitment has mediating effect midst Emotional Intelligence and employee performance. Practical implementation from this investigation suggest that the company can implemented the strategy to increase the Job performance based on the company strategy by Emotional Intelligence.
\end{abstract}

Keywords-emotional intelligence, employee performance, organizational commmitment, and private hospital

\section{INTRODUCTION}

The health care system is a labor-intensive sector that has undergone many changes as a result in the era of globalization, developments in various fields have made competition even superior. HR (human refounts) itself is one of the crucial things in reserve to achieve progress and performance of the organization in reserve to face competition. HRM regards employees as assets that must be valued and are a fount of competitive gain through commitment, accordance, and superior-stage dexterity and peak performance [1]. As time goes by, organizations must be able to develop and maintain their human refounts, the quality of a human refount is increasingly prominent and requires organizations to respond to the challenges of an ever-changing environment.

The success of a company's performance can be seen from the Job Performance that has been achieved by its human refounts, that's why the organization requires its employees to produce optimal performance. Job Performance is the designation of the work quality of an employee or human refounts [2]. Many factors affect Job performance, one of which is Emotional Intelligence [3]. Furthermore, Emotional Intelligence is cohesive to Organizational Commitment [4].
Human refounts who can recognize and express emotions, comprehend their own emotions and those of others, and are able to effectively control the emotional state at work, tend to have a stronger organizational commitment to the company than human refounts that have low aspects of Emotional Intelligence [5].

Human refounts with superior Emotional Intelligence are more adaptable to situations and show the aptitude to react in a more mature and controlled way in a crisis situation than people with low Emotional Intelligence. They can do things in a better way and perform better compared to others [6]. This encourages the authors to conduct investigation on human refounts in hospital services to anatomize their job performance by taking into account the factors that influence it, namely Emotional Intelligence, and Organizational Commitment as mediating variables.

\section{LITERATURE REVIEW}

\section{A. Emotional Intelligence}

Emotional Intelligence is delineating as the insight, judgement, and management of emotions in yourself and people [7]. It is said that Emotional Intelligence is a notion that tries to associate emotions, cognition, and metacognitive processes [8]. Emotional Intelligence is not a one character or aptitude, but is a combination of various affects and argumenting abilities [9]. Emotional Intelligence is the aptitude to comprehend and express affects, assimilate affects in the mind, comprehend and argument with affects, and regulate affects in self and others [10].

Emotional Intelligence (EI) in health services, although not mentioned or as an integral part of the health service infrastructure, is in fact interwoven into everything that is delivered as part of service provision [11]. In fact, EI is a prominent notion to be integrated into health care organizations; at all employee stages. Emotional Intelligence has been suggested as a key reference in all clinical procedurings - from board rooms and chairman's offices to wards and beds [12]. 


\section{B. Organizational Commmitment}

Organizational Commitment is a prominent notion in names of employee fidelity and usefulness for a comity [13]. Organizational Commitment is very prominent for comity that have a wish to withstand accomplished workers. This is the stage at which employees associate with the organization [14].

Of course, Organizational Commitment of employees is one of the attitudes that can lead to superior performance. Organizational Commitment is a significant factor affecting employee work results, and is a prominent indicator for performance [15]. More specifically employees who are committed to their organization tend to produce better performance than employees who are less committed, because they make more efforts on behalf of the organization towards the success of the organization itself and strive to achieve the goals and mission of the organization [16]. Employees with superiorer commitment scores are expected to be more motivated and perform at the superiorest stage of performance [13].

\section{Job Performance}

Job Performance is said as how well an employee can deliver their tasks to certain organizations [17]. Furthermore, Job Performance is defined as work-cohesive outcomes that refer to goals to achieve organizational goals as measured by performance judgements on work-cohesive tasks themselves [18]. Job Performance is "actions, behaviors, and measurable results, involving or brought by employees cohesive to contributions to organizational goals [19]. Likewise, there is the idea that Job Performance is evaluative, episodic, and multidimensional behavior which must be evaluated over a certain period of time and consists of a series of objectives [2022].

A superior stage of Job Performance leads to organizational productivity which in turn leads to success [23]. Job Performance is a very big factor that affects the profit aptitude of any organization [24]. Performance is prominent for organizations because employee performance leads to business success. Effectiveness for competitive gain mainly depends on the performance of the workforce, which means Job performance results such as productivity and output, are prominent for organizations to remain competitive in the market [25]. In addition, performance is prominent for individuals, because achieving tasks can be a fount of achieving shared goals [26]

\section{Hypothesis Development Investigation}

In a study by several investigationers of academic administrators at 3 universities in Malaysia, a positive and significant relationship was found midst Emotional Intelligence and Job performance [27]. Some investigationers in their investigation report that there are good influences caused by good Emotional Intelligence of employees on Job Performance of employees [28]. Correspondingly, a investigationer in his investigation also found a direct and positive relationship midst
Emotional Intelligence and Job Performance [29]. Based on this information, the formulation of the investigation hypothesis is:

H1: Emotional Intelligence has a positive and significant influence on Job Performance.

In a study of employees of multinational organizations in India, it was found that Emotional Intelligence had a direct relationship with Organizational Commitment [30]. In other studies, also found that employees with superior Emotional Intelligence will produce good organizational commitment [31]. Then, other studies found a positive influence caused by the employee's emotional intelligence on job satisfaction [32]. Based on this information, the formulation of the investigation hypothesis is:

$\mathrm{H} 2$ : Emotional Intelligence has a positive and significant influence on Organizational Commitment.

Based on the results of a study of employees working in the Automotive industry, Punjab, India stated that employees who have an Organizational Commission will produce good performance [33]. In other studies, found a direct significant relationship midst Organizational Commission and Job Performance [34]. in other studies, it has also been suggested that Organizational Commission has a positive influence on Job Performance [35]. Based on this information, the formulation of the investigation hypothesis is:

H3: Organizational Commission has a positive and significant influence on Job performance.

In a study of employees from the University of Jordan it was shown that those who had superiorer Emotional Intelligence had better performance than those who had lower EI, because those who had superiorer Emotional Intelligence were generally more contented with their work and those who were more contented with their work performing better than those who are less contented with their work [36]. This is also supported by other investigation which states that good employee Emotional Intelligence has a positive effect on Organizational Commitment which then also has a significant and positive effect on Job Performance [37]. Based on this information, the formulation of the investigation hypothesis is:

H4: Emotional Intelligence has a positive and significant influence on Job Performance with Organizational Commission as a mediating variable.

\section{METHODS}

Verifying data and hypotheses in investigation using statistical analysis tools Structural Equation Model (SEM) with the Linear Structural Relationship (LISREL) program. The population in this study conducted in October to December at the Private Hospital in Lampung are employees, consisting of: doctors, nurses, operators, pharmacy staff, admin / and others). Sampling itself is carried out using the sampling method used by Hair [38] that the number of samples is five to ten times the total investigation indicators, and in this study using twenty- 
seven indicators, so that the minimum sample size of 135 (one hundred thirty-five). The number of questionnaires distributed was 300. the questionnaire that was returned to the author and filled in completely was 251 , so the sample was sufficient to represent the number of respondents needed. The variable Emotional Intelligence was measured by submitting 16 statements divided into four dimensions [39]. The Job Satisfaction variable is measured by three indicators [40], which were then developed in 2013 [14], and the Job performance variable is measured using eight indicators [41].

\section{RESULTS AND DISCUSSION}

\section{A. Results}

The results of data processing are carried out to verify the hypothesis, as delineate in Table 1 below:

TABLE I. HYPOTHESIS VERIFY

\begin{tabular}{|l|l|l|l|}
\hline Hypothesis & Coefficient & P-value & Decision \\
\hline $\begin{array}{l}\text { H1:Emotional Intelligence has a } \\
\text { positive and significant influence } \\
\text { on Job Performance }\end{array}$ & 0.47 & 0.00 & Supported \\
\hline $\begin{array}{l}\text { H2:Emotional Intelligence has a } \\
\text { positive and significant influence } \\
\text { on Organizational Commitment }\end{array}$ & 0.37 & 0.00 & Supported \\
\hline $\begin{array}{l}\text { H3: Organizational Commitment } \\
\text { has a positive and significant } \\
\text { influence on Job performance. }\end{array}$ & 0.25 & 0.00 & Supported \\
\hline $\begin{array}{l}\text { H4: Emotional Intelligence has a } \\
\text { positive and significant effect on }\end{array}$ & 0.09 & 0.00 & Supported \\
Job Performance with \\
$\begin{array}{l}\text { Organizational Commission as a } \\
\text { mediating variable. }\end{array}$ & & & \\
\hline
\end{tabular}

Fount: data processed

\section{B. Discussion}

Hypothesis 1: The Effect of Emotional Intelligence on Job Performance.

Based on the results of data processing for verifying the effect obtained a positive coefficient $=0.47$ and a significance value ( $p$ value) of 0.00 . So that shows that Emotional Intelligence has a positive and significant effect on Job Performance. Thus the first hypothesis is accepted.

$\mathrm{H} 2$ : Emotional Intelligence has a positive and significant influence on Organizational Commitment.

Based on the results of a study of employees working in the Automotive industry, Punjab, India stated that employees who have an Organizational Commission will produce good performance [33]. In other studies, found a direct significant relationship midst Organizational Commission and Job Performance [34]. in other studies, it has also been suggested that Organizational Commission has a positive influence on Job Performance [35]. Based on this information, the formulation of the investigation hypothesis is:
H3: Organizational Commission has a positive and significant influence on Job performance.

In a study of employees from the University of Jordan it was shown that those who had superiorer Emotional Intelligence had better performance than those who had lower EI, because those who had superiorer Emotional Intelligence were generally more contented with their work and those who were more contented with their work performing better than those who are less contented with their work [36]. This is also supported by other investigation which states that good employee Emotional Intelligence has a positive effect on Organizational Commitment which then also has a significant and positive effect on Job Performance [37]. Based on this information, the formulation of the investigation hypothesis is:

H4: Emotional Intelligence has a positive and significant influence on Job Performance with Organizational Commission as a mediating variable.

\section{CONCLUSION}

Based on the findings and verifying of hypotheses that have been delineate, several conclusions can be drawn from the results of this study: (1) Emotional Intelligence has a positive and significant impact on Job Performance. (2) Emotional Intelligence has a positive and significant influence on Organizational Commitment (3) Organizational Commitment has a positive and significant effect on Job Performance. (4) Organizational Commitment can mediate the positive and significant influence of Emotional Intelligence on Job Performance.

Improving the aptitude of workers to control emotions, one of which is to quickly calm down when frustrated or angry through a spiritual splash in accordance with their respective beliefs that can be carried out by organizational management routinely for the workforce. Holding EI training classes and workshops that can be given to them in the hope of increasing calm in dealing with problems and finding solutions, and in general being able to have a good comprehending of one's own emotions. The holding of Outbound, Bootcamp, or Study Tour to a place with a comfortable environment with all workers without exception, can increase unity among workers without limitation so that they can better comprehend the attitudes and emotions of themselves and their colleagues. Management must increase the fidelity and wish of workers to stay together and feel reluctant to leave the organization. Building trust midst management and the workforce, can also be done by providing enough time for the workforce to complete the work and the existence of training according to work needs. Management can also provide clear and appropriate tasks in the workforce's competence, involve the workforce in determining performance standards and measures, and provide advice and assistance to employees in completing their duties. Suggestions that can be given to further investigationers is that for future investigation to add more supporting variables that form Job Performance, so that it is more enriching findings about factors that influence Job Performance, for example with the variable 
Person-organizational fit [42], Job stress [43], career development [44], work environment [45], organization commitment [46] and work passion [47]. This investigation was conducted on the object of investigation on health services such as hospitals, so that investigationers could further develop other investigation objects such as other service industries or manufacturing industries, and others.

\section{REFERENCES}

[1] M. Armstrong, Armstrong's handbook of human refount management practice (11 ed.). London: Kogan, 2009.

[2] J.G. Caillier, "Factors affecting job performance in public agencies," Public Performance and Management Review, vol. 34, no. 2, pp. 139 165, 2010.

[3] D. Goleman, R.E. Boyatzis, and A. McKee, Primal Leadership: Unleashing the Power of Emotional Intelligence: Harvard Business Press, 2013

[4] S. Cherian, A.J. Alkhatib, and M. Aggarwal, "Relationship Midst Organizational Commitment and Job Satisfaction of Nurses in Dubai Hospital," Journal of Advances in Social Science and Humanities, vol. 4, no. 1, pp. 36373-36400, 2018.

[5] R. Abraham, "Emotional Competence as Antecedent to Performance: A Contingency Framework, Genetic, Social and General Psychology Monographs," vol. 130, no. 2, pp. 117-143, 2004

[6] M. Sony and N. Mekoth, "The relationship midst emotional intelligence, frontline employee accordance, job satisfaction and job performance," Journal of Retailing and Consumer Services, vol. 30, pp. 20-32, 2016

[7] J.D. Mayer, R.D. Roberts, and S.G. Barsade, "Human abilities: Emotional intelligence," Annu. Rev. Psychol., vol. 59, pp. 507-536, 2005 .

[8] A.S. Drigas and C. Papoutsi, "A New Layered Model on Emotional Intelligence. Behavioral Sciences,” Journal of Psychology, vol. 8, no. 5, p. $45,2018$.

[9] A.O. Afolabi, "Influence of five-factor personality attributes, need for achievement and Emotional intelligence on work team interaction processes in the Niger-Delta," Unpublished.

[10] R.J. Sternberg and S.B. Kaufman, The Cambridge Handbook of Intelligence. New York, NY: Cambridge University Press, 2011.

[11] Y.F. Birks and I.S. Watt, "Emotional intelligence and patient-centred care," J R Soc Med, vol. 100, no. 8, 2009.

[12] R.M.J. Bohmer, "Leading clinicians and clinicians leading," N Engl J Med, vol. 368, no. 16, pp. 1468-1470, 2013.

[13] A. Berberoglu and H. Secim, "Organizational commitment and perceived organizational performance among health care professionals: Empirical evidence from a private Hospital in Northern Cyprus," Journal of Economics and Behavioral Studies, vol. 7, no. 1, pp. 64-71, 2015.

[14] W. Fu and S.P. Deshpande, "The imapct of caring climate, Job satisfaction, and Organizational Commitment on Job Performance of Employees in A China's Insurance Company," Journal Business Ethics, vol. 124 , no. 2 , pp. 339-349, 2013

[15] K.M. Dirani, "Measuring the learning organization culture, organizational commitment and job satisfaction in the Lebanese banking sector," Human Refount Development International, vol. 12, no. 2, pp. 189-208, 2009.

[16] M.H. Jafri and T. Lhamo, "Organizational commitment and work performance in regular and contract faculties of Royal University of Bhutan," Journal of Contemporary Investigation in Management, vol. 8, no. 2, pp. 47-58, 2013
[17] A.F. Femi, "The impact of communication on workers' performance in selected organisations in Lagos State, Nigeria," Journal Of Humanities and Social Science, vol. 19, no. 8, pp. 75-82, 2014.

[18] D. Sharma, S. Borna, and J.M. Stearns, "An Investigation of the Effect of Corporate Ethical Values on Employee Commitment and Performance: Examining the Moderating Role of Perceived Fairness," Journal of Business Ethics, vol. 89, no. 2, pp. 251-260, 2009.

[19] J. Pandey, "Factors Affecting job performance: An Integrative Review of Literature," Management Investigation Review, vol. 42, no. 2, pp. 263-289, 2019.

[20] R.R. Kehoe and P.M. Wright, "The impact of superior-performance human refount practices on employees' attitudes and behaviours,' Journal of Management, vol. 39, no. 2, pp. 366 - 391, 2013.

[21] J. Singh and M. Jain, "A Study of Employees' Job Satisfaction and Its Impact on their Performance," Journal of the Indian Investigation, vol. 4, pp. 105-111, 2013.

[22] M. Javed, Balach and F. Hassan, "Determinants of Job Satisfaction and its impact on employee Performance and Turnover Intentions," International Journal of Learning and Development, vol. 4, no. 2, pp. 120-140, 2014.

[23] M.A. Wattoo, "Superior-performance work systems and work-family interface: job autonomy and self-efficacy as mediators," Asia Pacific Journal of Human Refounts, vol. 2, pp. 10-18, 2019.

[24] S. Bevan, "Good work, Superior performance and productivity," The paper prepared for the European HRD Forume, Lisbon, 2012.

[25] R. Daeley, Organisational Behavior Edinburgh Business School, HeriotWatt University, 2012.

[26] D.S. Muchhal, "HR Practices and Job Performance," IOSR Journal of Humanities and Social Science (IOSR-JHSS), vol. 19, no. 4, pp. 55-61, 2014.

[27] Mahdinezhad, Shahhosseini, Kotamjani, Bing and Hashim, "Emotional Intelligence and Job Performance: A Study among Malaysian Administrator," International Journal of Academic Investigation in Business and Social Sciences, vol. 7, no. 6, 2017.

[28] N. Shamsuddin and R.A. Rahman, "The Relationship midst Emotional Intelligence and Job Performance of Call Centre Agents," Procedia Social and Behavioral Sciences, vol. 129, pp. 75-81, 2014

[29] M. Vahidi, H.N. Areshtanab, and M.A. Bostanabad, "The Relationship midst Emotional Intelligence and Insight of Job Performance among Nurses in North West of Iran," Scientifica, vol. 1-5, 2016.

[30] S. Shukla, B. Adhikari, and M. Ray, "Emotional Intelligence and Job Satisfaction: An Empirical Investigation," Amity Global HRM journal, vol. 6, pp. 54-61, 2016.

[31] N.A. Nahid, "Teachers: emotional intelligence, job satisfaction, and organizational commitment," Journal of workplace Learning, vol. 24, no. 4, pp. 256-269, 2011.

[32] C.S. Long, M. Yaacob, and T.W. Chuen, "The impact of emotional intelligence on job satisfaction among teachers," International Journal of Management, Accounting and Economics, vol. 3, no. 8, pp. 544-552, 2016

[33] M. Shaju and D. Subhashini, "A study on the impact of Job Satisfaction on Job Performance of Employees working in Automobile Industry, Punjab, India,” Journal of Management, vol. 9, no. 1, 2016.

[34] B. Vermeeren, B. Kuipers, and B. Steijn, "Does leadership style make difference? Linking HRM, job satisfaction, and organizational performance," Review of Public Personnel Administration, vol. 34, no. 2, pp. 174-195, 2014.

[35] M.R. Khan, F.A. Ziauddin, and M.I. Ramay, "The impacts of Organizational commitment on employee job performance," European Journal of Social Sciences, vol. 15, no. 3, pp. 292-298, 2010.

[36] I. Vratskikh, R. Masa'de, M. Al-Lozi, and M. Maqableh, "The Impact of Emotional Intelligence on Job Performance via the Mediating Role of Job Satisfaction," International Journal of Business and Management, vol. 11 , no. 2 , pp. 69-91, 2015 
[37] M. Pugno and S. Depedri, "Job Performance and Job Satisfaction: An Integrated Survey," Department of Economics Working Papers: University of Trento, Italia, 2009.

[38] J.F. Hair, W.C. Black, B.J. Babin, and R.E. Anderson. Multivariate Data Analysis. New York : Pearson, 2010.

[39] C.S. Wong and K.S. Law, "The Effects of Leader and Follower Emotional Intelligence on Performance and Attitude: An Exploratory Study, The Leadership Quarterly," vol. 13, no. 3, pp. 243-274, 2002.

[40] A.J. Cellucci and D.L. Devries, "Measuring managerial satisfaction: A manual for the MJSQ," Journal of Technical Report, vol. 11, no. 5, 1978.

[41] A. Eckhardt, S. Laumer, C. Maier, and T. Weitzel, "The effect of personality on IT personnel's job-cohesive attitudes: estabilishing a dispositional model of turnover intention across IT job types," Journal Information Technology, pp. 48-66, 2016.

[42] A.H. Ramli, "Person-Organization Fit dalam Rantai Distribusi Pemasaran," Jurnal Manajemen dan Pemasaran Jasa, vol. 12, no. 1, pp. 77-92, 2019.
[43] A.H. Ramli, "Compensation, Job Satisfaction And Employee Performance In Health Services," Business And Entrepreneurial (BER), vol. 18, no. 1, pp. 85-94, 2018

[44] A.H. Ramli and R. Yudhistira, "Pengaruh Pengembangan Karir terhadap Kinerja Karyawan melalui Komitmen Organisasi pada PT. Infomedia Solusi Humanika di Jakarta," ProsidingSeminar Nasional Cendekiawan ke-4 tahun 2018, Lembaga Penelitian Universitas Trisakti, pp. 811-816, 2018.

[45] A.H. Ramli, "Work Environment, Job Satisfaction and Employee Performance in Health Services," Business and Entrepreneurial Review, vol. 19, no. 1, pp. 29-42, 2019.

[46] A.H. Ramli and S. Mariam, "Organisational Commitment And Job Performance In Banking Industry,” International Journal of Scientific \& Technology Investigation, vol. 9, no. 3, 2020.

[47] S. Mariam and A.H. Ramli, "The Effect of Work Passion, Work Engagement, and Job Satisfaction on Turnover Intention (Empirical Study : PT. Bank Mandiri (Persero), Tbk)" The 1st International Conference on Business, Accounting, Supply Chain and Logistics, p. $219,2019$. 